\title{
AANTEEKENINGEN BETREFFENDE STEVEN VAN DER HAGEN.
}

DOOR

\author{
Dr. J. W. IJZERMAN.
}

(Met kaart.)

Van geen der vlootvoogden uit den eersten tijd der vaart op OostIndië zijn meer levensbijzonderheden bekend dan van Admiraal Steven van der Hagen. In het Rijksarchief berust het eigenhandig door hem geschreven verhaal zijner lotgevallen van $1575-1599^{1}$ ), terwijl zijn verder openbaar leven uit de journalen zijner reizen en andere gedrukte stukken kan worden gevolgd.

In zijn manuscript verhaalt hij, hoe hij als knaap van 12 jaar de wijde wereld inging, en van loopjongen in een winkel en knecht bij een aanzienlijk Spaansch edelman opklom tot bevelhebber eener groote vloot van de Vereenigde Oost-Indische Compagnie. Bij het doorlezen van deze in menig opzicht zoo belangwekkende avonturen, valt het op, dat hij omtrent zijn naaste familiebetrekkingen, na enkele korte mededeelingen uit zijn jeugd, niets meer vermeldt. Hij noemt zijn grootvader, die zijn prille jeugd bewaakte; zijn oom, die hem een tweede te huis bezorgde; zijn vader, met wien hij betrekkelijk weinig aanraking had en zijn moeder, die hij jong verloor. Maar over zijn huwelijk, zijn vrouw, zijn zoon en zijn kleinkinderen, kortom over zijn eigen gezin bewaart hij het meest volstrekte stilzwijgen.

Dank zij de nasporingen van den Heer P. F. L. C. Lach de Bère, waarvan het resultaat als Bijlage hierachter is opgenomen, zijn we thans in staat gesteld, bij de opsomming van enkele feiten uit het veelbewogen leven van Van der Hagen, ook over de genoemde leemten eenig licht te doen opgaan.

Steven, zoo blijkt dan, was de oudste van drie kinderen uit het huwelijk van Andries van der Hagen en Maria van Surckestein. Hij werd, zooals uit verschillende eigen opgaven kan worden afge-

1) Kol. Aanwinsten 213, uitgegeven door P. A. Tiele in de Bijdr. en Med. van het Hist. Gen. te Utrecht 1883 p. $377-421$. 
leid, geboren in 1563 te Amersfoort. Zijn vader, een Zuid-Nederlander, hield evenals diens twee broeders in Vlaanderen verblijf. Zijn moeder was de dochter van Gosen Lubbertsen van Surckestein en volgde haar echtgenoot naar Brugge. Steven bleef aanvankelijk bij zijn grootvader, die hem onderricht gaf of liet geven in het latijn. Tien jaar oud werd hij door zijn vader naar Brugge geroepen. Daar ging hij eerst korten tijd school, kwam toen een jaar bij een lakenkooper te Doornik en vervolgens op het kantoor van zijn oom Willem van der Hagen, die als commissionair voor den doorvoer van goederen te Yperen werkzaam was. Bij dezen strengen meester hield hij het niet lang uit. In 1575 liep hij weg; welwillende kooplieden namen hem te Calais aan boord en brachten hem naar Spanje, het doel zijner wenschen. Hier bleef hij drie jaar. Bij zijn terugkomst in October 1578 trof hij zijn grootvader niet meer aan. Van den eenigen broeder zijner moeder, Roelof, vernam hij, dat zij overleden en zijn vader reeds anderhalf jaar te voren hertrouwd was. Hij bleef den winter in Amersfoort over, bracht daarna enkele maanden bij zijn ouders te Yperen door en keerde in Augustus 1579 naar zijn oom terug. Voorzien van eenig geld uit zijn moeders erfdeel, vertrok hij weldra over land naar Italië, waar hị het italiaansch op dezelfde wijze als vroeger het spaansch praktisch meester werd.

$\mathrm{Na}$ een paar andere dienstbetrekkingen kwam hij terecht bij den Onderkoning van Napels Don Juan de Zuniga, in wiens gevolg hij mede reisde naar Spanje. In November 1582 vertrokken, kreeg hij bij het langzaam volgen der kust tot Barcelona, een goede gelegenheid om kennis op te doen van de handelsbeweging in verschillende havens, waar in dien tijd verscheidene Engelsche schepen verkeerden. Het laatst van September 1584 zag hem weder in Amersfoort terug.

Het volgende jaar, bij zijn vader te Yperen vertoevende, maakte hij bij een bezoek aan Calais, in Augustus 1585 kennis met schipper Reynier Pietersz van Twisch, door wiens tusschenkomst hij in aanraking kwam met Hoornsche reeders. Deze zonden hem met een lading gedroogde visch via Ayamonte en Valencia naar Genua, de eerste Nederlandsche vaart naar de Oostkust van Spanje en de Westkust van Noord-Italië. De afloop dezer onderneming was allerongelukkigst. Na zijn schip de Witte Leeuw in de baai van Cadix bij den aanval van Francis Drake in 1587 verloren te hebben, en op de terugreis door een Engelsch schip van al zijn goed beroofd te zijn, bracht hij zijn meesters te Hoorn de droeve tijding van het gebeurde. 
Hij had echter hun vertrouwen niet verloren. Reeds in Januari 1588 volgde een nieuwe reis, nu met een grooter schip, een der bekende Hoornsche „Verlangens”. Bijna was deze even onfortuinlijk verloopen als de vorige, want bij den terugkeer van Genua, werd hij te Valencia aangehouden. Hij slaagde er echter in schip en lading in veiligheid te brengen. Zelf achtergebleven, herkreeg hij door zijn vroegere relaties reeds in Maart de vrijheid. In Juni 1589 meldde hij zich te Hoorn, om daarna ,zijn vrienden”, d.i. zijn bloedverwanten, te Amersfoort op te zoeken.

In dienst van Amsterdamsche kooplieden gekomen, die het voorbeeld van Hoorn wilden volgen, volbracht hij eerst een reis naar Alicante en Valencia. Op een tweede ging hij vooruit van Bilbao over land naar Valencia om de lading gereed te maken, en keerde hij op dezelfde wijze over Madrid en La Rochelle terug. 24 Juni 1591 was hij weder te Amsterdam.

Hij was toen 28 jaar. Kort daarna schijnt hij tijd gevonden te hebben om in het huwelijk te treden. Zelf maakt hij van dit gewichtig feit in zijn leven niet direct melding.

Hij kreeg en aanvaardde een opdracht van kooplieden van Amsterdam en Haarlem om naar Spanje te gaan en daar te beproeven twee door den Adelantado in beslag genomen schepen los te krijgen. 23 Februari 1592 begaf hij zich op weg. Zijn poging mislukte en de reis duurde langer dan hij vermoed had. Met nieuwjaar 1593 uit Milaan vertrokken, voer hij den Rijn af naar Utrecht, waar hij ,wonachtig was”, en 3 Februari aankwam. Eerst daarna ging hij naar Amsterdam, om verslag aan zijn lastgevers te doen.

Zijn eerste bezoek gold dus zijn vrouw, Stephania van der Maet, mogelijk een dochter of kleindochter van Stephania van Oudewater en den hier achter genoemden reeds in 1568 overleden Jan Philips van der Maten. Zij schonk hem een zoon Cornelis. $\mathrm{Nu}$ was het voorloopig met zijn zwerven gedaan. Hij bleef te Utrecht, ,sijn rust houdende ende geneerde hem met inlandsche handelinge, also hij die reyse op Spaengien moede was, ende dat men daer met groote periklen varen moeste".

In October 1594 deed hij. mede handelende voor zijn broeder Willem en zijn zuster Catharina, welke getrouwd was met den schout van Breukelen, Cornelis van den Bongaert, uit hun moederlijk erfdeel de helft van een huis en hofstede buiten Amersfoort aan zijn oom Roelof over.

Veel langer dan 4 jaar hield hij het thuis niet uit. Toen volgden 
drie reizen. Eerst van 12 Juli 1597 tot 11 Maart 1598 met 2 schepen naar de kust van Guinee; toen van 6 April 1599 tot September 1601 met de Son, Maen en Sterre naar Oost-Indië en vervolgens van 18 December 1603 tot 22 Juli 1606 met 12 schepen voor rekening van de Vereenigde Oost-Indische Compagnie. Op deze laatsten tocht veroverde hij het eiland Ambon op de Portugeezen, waar hij 1 Maart 1605 Frederik de Houtman als eersten gouverneur aanstelde. Bij de overgave van het fort vergunde hij an de beide Katholieke missionarissen en eenige Portugeezen met hun gezin op Ambon te blijven, een daad, die zijn goede hart eer aandoet, maar onder de bestaande omstandigheden een groote politieke misslag was.

De eerstvolgende jaren bracht hij in ontevreden stemming door, murmureerende over minder loyale behandeling door de Bewindhebbers der Compagnie. Hij zal zijn deel in den waarschijnlijk door zijn vrouw reeds lang gedreven binnenlandschen handel toen wel hervat hebben. 7 April 1610 werd op zijn naam overgeschreven een huis aan de Westzijde van de Oudegracht te Utrecht. De koopprijs is niet vermeld; wel blijkt dat hij voor de betaling een hypotheek sloot bij den schoenmaker Jan van Broeckhuysen.

Ten einde aan zijn billijke klachten tegemoet te komen, werd hij benoemd tot lid in den Raad van Indië, in welke waardigheid hij 2 Juli 1613 met den Gouverneur Generaal Reynst, als admiraal van 4 schepen naar Bantam voer. Met het oog op zijn aanstaand vertrek zal mogelijk het huwelijk van zijn zoon Cornelis, die toen ruim 20 jaar oud zal zijn geweest, vervroegd zijn; ten minste dit werd 12 April 1613 met Anna Uyttenbogaert te Utrecht gesloten.

Van der Hagen bleef bijna volle 7 jaren uit. Eerst 23 Juni 1620 liep hij te Hellevoetsluis binnen.

Geërgerd over de aanmatiging van Frederik de Houtman, die op een kaart van Ambon diens portret als veroveraar van dat eiland had doen schilderen, kreeg hij 20 September 1620 van Heeren XVII met een vereering van $f \mathbf{2 0 0 0}$, de genoegdoening, dat deze kaart zou worden verwijderd en vervangen door een andere, waarop hij zelf zijn eigen beeltenis kon doen afmalen ${ }^{1}$ ). Dat hij die kaart werkelijk

1) Het voorgevallene in de vergadering van de Bewindhebbers volgt hieronder :

Woensdach 30 September 1620.

Den Admirael Steven van der Hagen is binnen gestaen ende heeft overgegeven aen de Heren van de Seventhiene sijne schriftelijcke Journalen van de reijse bij hem gedaen naer Indien, ende de victorien ende exploicten, die hij 
heeft laten schilderen, is niet gebleken. Te vergeefs zoekt men tot dusverre naar zijn portret.

$\mathrm{Hij}$ had het groote verdriet zijn eenigen zoon, drie jonge kinderen achterlatende, op 17 November 1622 te verliezen.

Den 30sten Mei 1623 woonde hij niet meer in, maar buiten de stad. Op dien datum liet hij gelden invorderen, waaruit de aard van den door hem en zijn vrouw gedreven handel blijkt. Zijn rekeningen hadden betrekking op garen en lint. Rustig bedrijf aan het einde van een zoo bewogen loopbaan!

Hij werd 29 Juli 1624 in de Jacobikerk te Utrecht begraven. De curatoren van zijn boedel verkochten 15 Augustus 1625 voor zijn erven, zijn weduwe en zijn kleinkinderen, zijn huis met omliggend

gedurende dien tijt geluckelijck heeft beleyt, als oock sijne schriftelijcke remonstrantiën, die hij bij monde oock heeft verhaelt, ende dewijle alles was tenderende, om over diversche sijnne pretentiën met een vereeringhe gerecognoisseert te werden, soo is naer lecture ende consideratie van de voornoembde schriftelijcke ende mondelinge remonstrantie, hem aengesijt, dat de Comp" aencaende t'gene hij in sijn voyagie in de Conqueste van Amboyna ende diergelijcke soude mogen hebben geimploijeert tot reputatie vant Landt ende der Vereenichde Oost-Indische Comp ${ }^{\circ}$ niet en is gehouden ofte verobligeert, also bij sijnne laeste aenneminghe ende form van Contract hij alles hadde gerenuncieert, ende tot consideratie van dien synne maentgelden soo waren verhoocht ende dat aengaende d'eere, die hij pretendeerde te hebben als conquesteur vant Casteel ende landen van Amboyna, dat dese vergaderinghe daer niet tegens en hadde.

Tot welcken eijnde de Caerte ende met het pourtraict van Frederick de Houtman in de grote zale hangende, soude werden wechgedaen ende wert aen hem gepermitteert, dat hij tot costen van de $\mathrm{Comp}^{\mathrm{e}}$ sal laten maecken eeil gelijcke caerte van den Landt van Amboijna, in dewelcke hij sal vermogen te stellen ofte laten schilderen sijn portraict met een Inscriptie als sijnde geweest den Conquesteur ende eerste Gouverneur van Amboyna onder de regeringe vain de Ho: ende Mo: Heeren Staten Generael, welcke Inscriptie hij eerst sal communiceren aen de Comp ${ }^{\circ}$ om geëxamineert te werden ende sal oock vermogen in een parcke in de voornoembde kaerte van Amboyna int cleijn laten affmalen de overwinninghe, die hij gehadt heeft over de vier gallioenen voor Mallacca tot een memorie van de voorsz. Heer Admirael ende alhoewel achtervolgende het contract met hem schriftelijck gemaeckt op synne laetste aenneminghe hij over het voornoembde exploict voor Mallacca ofte eenige andere dergelijcke vrome feijten niets en can pretenderen, soo hebben nochtans de Heren van de Seventhiene uijt een pure Liberalitijt ende gratuiteijt sonder daartoe verobligeert te sijn aen de voornoembde Admirael Steven van der Hagen vereert een gouden l:eten ter waerde van twee duysent guldens, $t$ sy in gelt ten prijse als boven cfte gemaeckt tot een kettingh, sooals het hem sal gelieven, ende dat voor alle pretentien, die hij voor desen, nu ofte naermaels op de Vereenichde Oost-Indische Comp ${ }^{*}$ sal mogen voortbrengen, gene uijtgesondert, welcke vereeringhe ende conditie hij heeft aengenomen, ende sijn de Seventhienen van hem daervoor bedanckt. 
terrein, genaamd Blijesteyn en gelegen bij de stad op het „Swarte Water".

Her origineel van de hiernevens afgedrukte kaart van Ambon, waarop de bijschriften, onder en naast het portret van Frederik de Houtman, zijn weggekrabt, bevindt zich in het Rijksmuseum te Amsterdam. ${ }^{1}$ )

1) Vèrgel. Navorscher 1898, bl. 140. 
BIJLAGE.

Betreffende Steven van der Hagen, gewezen admiraal in OostIndie, werd in de archieven te Amersfoort en Utrecht het navolgende gevonden op hem of naaste familieleden betrekking hebbende.

I. Andries van der Hagen, geh. Maria Gosens ${ }^{d}$ van Surckesteijn, beiden overleden vóór 10 Oct. 1594, lieten na:

1. Steven,

2. Willem, en

3. Catharina, geh. Cornelis van den Bongaert.

Deze kinderen transporteerden 10 Oct. 1594 land aan Jan Wouters, raijmaker. (Transportboek Amersfoort).

Steven van der Hagen, voornd, burger te Utrecht als gemachtigde van zijn broeder Willem (procuratie 30 Oct. 1594, verleden voor den procureur van de griffie van het hof van Utrecht) en van zijn zuster Catharina, geh. Cornelis van den Bongaert, schout te Breukelen (proc. 30 Nov. 1594, alsvoren) erfgenamen hunner ouders, transporteerden 22 Sept. 1595 de helft van huis en hofstede buiten de stad Amersfoort in den Bruel aan Roelof v. Surckesteyn. (Transportboek Amersfoort).

II. Willem van der Hage huwde 23/6 1601 te Utrecht Neeltje van Meteren (St. Geerte kerk).

III. De kinderen van Herbert van Haeften geh. Alidt Jan Boucamps, transporteerden 7 April 1610 aan Steven van der Hagen voortijds admiraal van de O. I. voijagie, geh. Stephania van der Maeth huis en hofstede aan de Westzijde van de Oude Gracht tusschen de Backer- en St. Jansbrugge op den hoek van de Vroetsteeg, strekkende voor van de gracht tot achter aan het huis van Goert Willems, daar dezelve steeg Noordwaarts en Jan Florisz Nijpoort Zuidwaarts naast gelegen zijn (Reg. transp. en plechten Utrecht deel 324, fol. 114 v.). Waarschijnlijk tot afbetaling van de koopsom sloten zij denzelfden dag een leening van f 1000 met Jan van Broeckhuijsen, schoenmaker, en stelden tot pand vorenbedoeld huis. (Id. fol. $116 \mathrm{v}$.).

Stephania van der Maeth voornd is mogelijk een dochter of eerder nog een kleindochter van Stephania van Oudewater wed $^{\mathrm{c}}$ v. Jan Philips van der Maten genoemd in acten 9/9 1568 en 12/12 1569 (Transpt. boek, als voren jaren 1568 en 1569). 
IV. Cornelis van der Hagen huwde te Utrecht in de Jacobi Kerk 12/4 1613 Anna Uijttenbogaert, beiden van Utrecht. Hunne kinderen waren (ged. Jacobi kerk):

1. Maria gd. 21 Dec. 1614,

2. Margaretta gd. 22 Sept. 1616,

3. Frans gd. 28 Sept. 1617.

Cornelis van der Hagen en Ruth Lamberts v. Emmelichoven assisteerden 6 Jan. 1618 Lucas de Jongh bij het opmaken der huw.voorw. met Mechteltgen van Broeckhuijsen, geassisteerd met haar vader Cornelis, wachtmeester, en haar neef Henrick van Broeckhuijsen. (192 Not. N. Verduijn, Utrecht).

Hij overleed 17 November 1622, genoemd Raad van de stad Utrecht (Navorscher 1886).

V. Steven van der Haghen gewezen admiraal in Oost-Indië en zijne huisvrouw Stephania van der Maet, wonende buiten de Weerde bij Utrecht, machtigden 30 Mei 1623 Andries Cornelisz lintwerker om een bedrag te innen van Peter Jans bierbeschoijer tot Meppel voor hem en als boedelhouder van zijn overl. huisvrouw Aelbertgen Roelofs ,ter cause van coopmanschappe en handelinge van gaern ende andere bij deselve Aelbertgen in haer leven met joffr. Stephania van der Maet gedaen". (192 Not. N. Verduijn, fol. 88 v.).

$\mathrm{Zij}$ lieten eveneens een bedrag innen van Isaacq de $\mathrm{Zijde}$, wonende in den Admirant en van Jan Marinus of Jan Maris in de Goudsblom, beiden op den Nieuwen dijk te Amsterdam ,tercause van coopmanschappe van lint". (Id. fol. 89 v.).

VI. Steven van der Hagen, admiraal, begraven 29 Juli 1624 Jacobi kerk te Utrecht; nalatende zijn huisvrouw en kindskinderen (Begraafboek Utrecht). Navorscher 1887 vermeldt in overluidingen Utrecht: Stephani v. d. Hagen 25 Juli 1624.

VII. Johan Blocq, wijnkooper te Utrecht, gemachtigde van Johan van Hoorn te Amsterdam kocht 15 Augustus 1625 van den curator boedel van Stephania van der Maet, wed van Steven van der Hagen, mitsgaders van de momboirs en voogden over de kinderen van Cornelis van der Hagen : „huijs met groote bongaert, moes- en cruijthof, gend. Blijesteijn ofte anders het rentmeesters huijsken gelegen bij de stad Utrecht op het Swarte water", benevens een stuk weiland en een hofje of warande achter den boomgaard van Blijesteijn met de plantage daarop staande (196 Not. W. van Galen. fol. 159). 